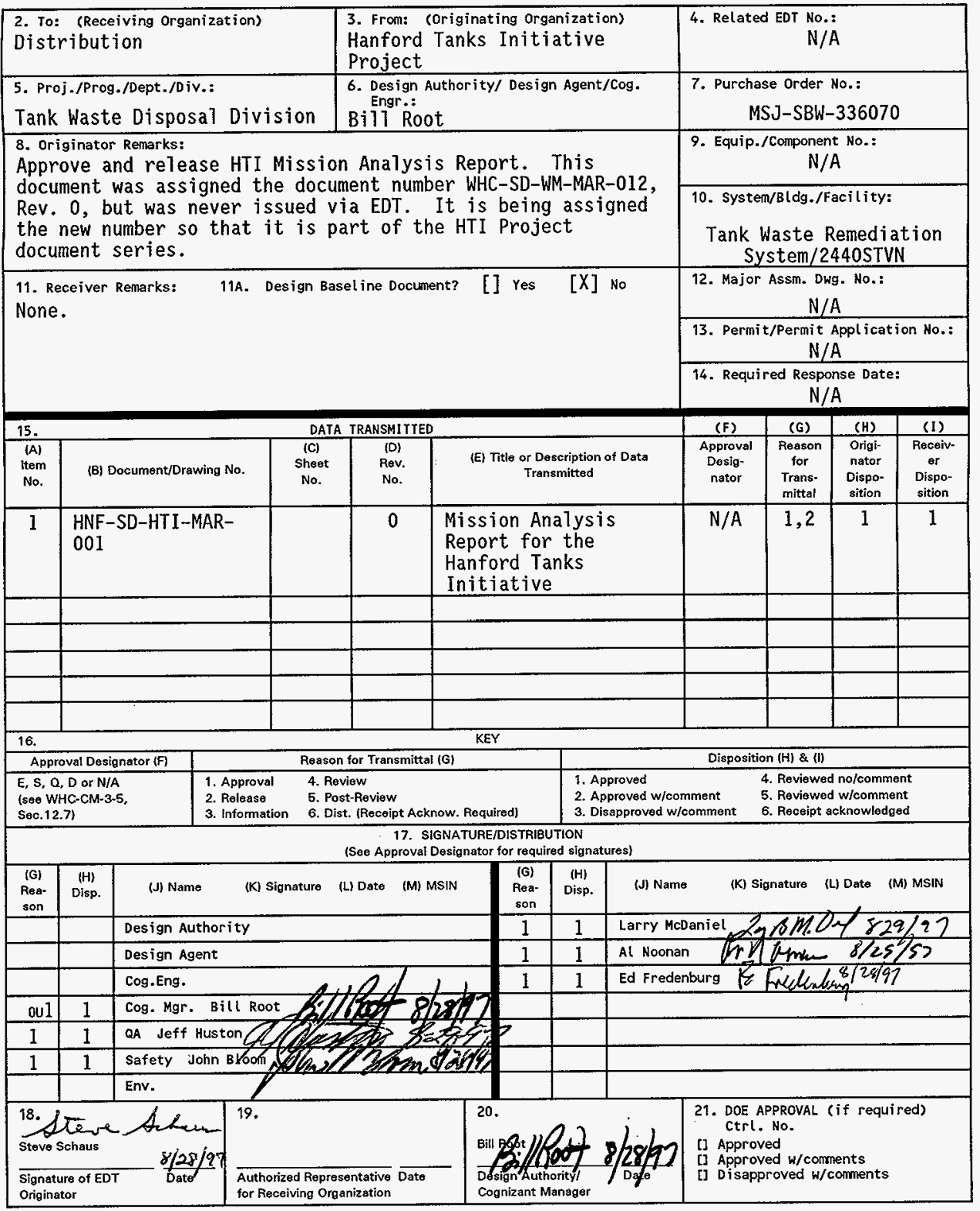




\section{MISSION ANALYSIS REPORT FOR THE HANFORD TANKS INITIATIVE}

\section{P.S. SCHAUS}

Lockheed Martin Hanford Company, Richland, WA 99352

U.S. Department of Energy Contract DE-AC06-96RL13200

Prepared by Los Alamos Technical Associates, Inc.

$\begin{array}{llll}\text { EDT/ECN: } & 622801 & \text { UC: } 2030 \\ \text { Org Code: } & 73500 & \text { Charge Code: } & \text { D26Al } \\ \text { B\&R Code: } & \text { EW4010000 } & \text { Total Pages: } 49\end{array}$

Key Words: Hanford Tanks Initiative, mission analysis report

Abstract: The HTI Project's Mission Analysis Report defines the mission statement and mission boundaries, the known interfaces, the top-level requirements, the test and evaluation methodology, and the measures of success for the HTI Project.

TRADEMARK DISCLAIMER. Reference herein to any specific commercial product, process, or service by trade name, trademark, manufacturer, or otherwise, does not necessarily constitute or imply its endorsement, recommendation, or favoring by the United States Government or any agency thereof or its contractors or subcontractors.

Printed in the United States of America. To obtain copies of this document, contact: Document Control Services, P.0. Box 950, Mailstop H6-08, Richland WA 99352, Phone (509) 372-2420;

Fax (509) 376-4989.
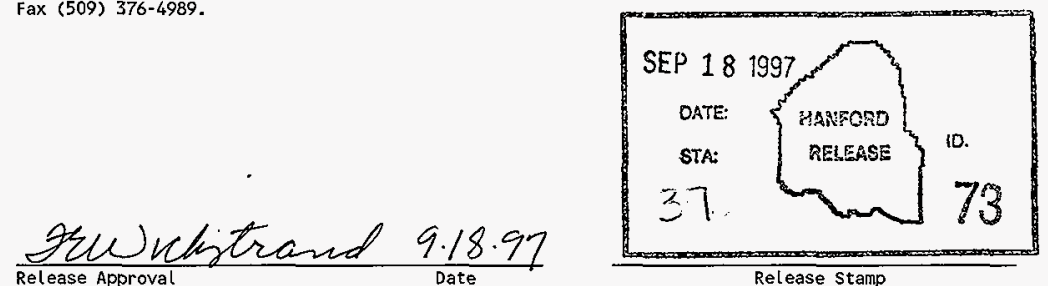

Release Approval

Date

Release Stamp

\section{Approved for Public Release}


This page intentionally left blank. 
CONTENTS

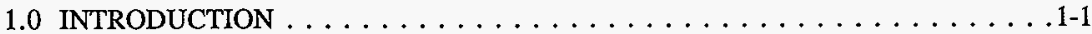

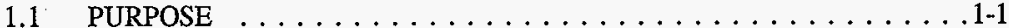

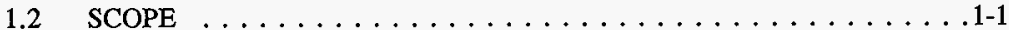

1.2.1 Scope of the Hanford Tanks Initiative $\ldots \ldots \ldots \ldots \ldots \ldots \ldots$

1.3 BACKGROUND . . . . . . . . . . . . . . . . .

1.3.1 Waste Retrieval Background . . . . . . . . . . . 1-2

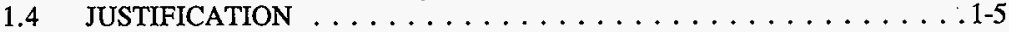

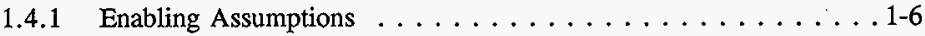

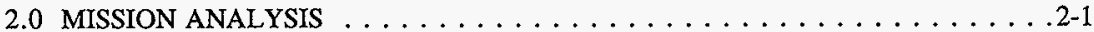

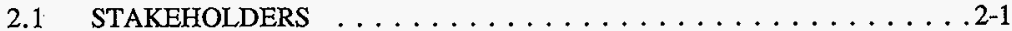

2.2 PROBLEM DEFINITION $\ldots \ldots \ldots \ldots \ldots \ldots \ldots \ldots \ldots . . \ldots \ldots$

2.3 INITIAL UNACCEPTABLE STATE $\ldots \ldots \ldots \ldots \ldots \ldots \ldots . . \ldots 2-3$

2.4 FINAL ACCEPTABLE STATE $\ldots \ldots \ldots \ldots \ldots \ldots \ldots \ldots .2-3$

2.5 SYSTEM BOUNDARIES AND EXTERNAL INTERFACES $\ldots \ldots \ldots 2-3$

2.5.1 System Boundaries and External Interfaces . . . . . . . . . 2-3

2.5.2 Physical Interface Boundaries . . . . . . . . . . . . . . . 2-3

2.6 MISSION STATEMENT, NEEDS, GOALS, AND OBJECTIVES $\ldots . .2-7$

2.6.1 Mission Statement . . . . . . . . . . . . . . . . . . 2-7

2.6 .2 Mission Needs . . . . . . . . . . . . . . . . . . . 2-7

2.6.3 Mission Goals and Objectives . . . . . . . . . . . . 2-8

2.7 MISSION LEVEL REQUIREMENTS . . . . . . . . . . . . . . . . . 2-10

2.8 TEST AND EVALUATION ANALYSES $\ldots \ldots \ldots \ldots \ldots \ldots .2-12$

2.9 TECHNICAL PERFORMANCES AND MEASURES $\ldots \ldots \ldots \ldots \ldots 2-13$

2.10 SYSTEM LIFE CYCLE $\ldots \ldots \ldots \ldots \ldots \ldots \ldots \ldots \ldots \ldots \ldots \ldots . . \ldots \ldots$

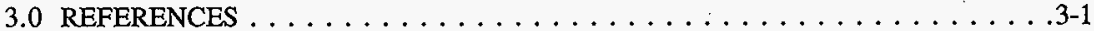

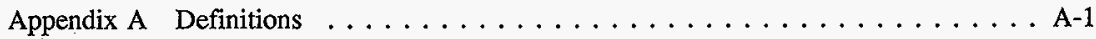

Appendix B Attachment 1, TPA Change Form M-45-93-01, Approved 1/25/94

Process for Determining the Limit of Technology for Single-Shell

Tank Retrieval . . . . . . . . . . . . . . . . B 1

Appendix C External Constraints and Requirements for Hanford Tanks Initiative . . . C-1 


\section{LIST OF FIGURES}

1-1. Components of the Retrieval Demonstrationthat Define the Limits of Technology. . 1-4

2-1. Tank 241-C-106 Heel Retrieval Systems and Physical Boundaries . . . . . . . . 2-5

\section{LIST OF TABLES}

2-1. Hanford Tanks Initiative Goals and Objectives $\ldots \ldots \ldots \ldots \ldots \ldots$ 2-8 


\section{LIST OF TERMS}

$\begin{array}{ll}\text { DOE } & \text { U.S. Department of Energy } \\ \text { DST } & \text { Double-Shell Tank } \\ \text { Ecology } & \text { Washington State Department of Ecology } \\ \text { EPA } & \text { U.S. Environmental Protection Agency } \\ \text { HTT } & \text { Hanford Tanks Initiative } \\ \text { ISSTRS } & \text { Initial Single-Shell Tank Retrieval System } \\ \text { NRC } & \text { Nuclear Regulatory Commission } \\ \text { PPS } & \text { past practice sluicing } \\ \text { PUREX } & \text { Plutonium Uranium Extraction } \\ \text { RAM } & \text { reliability, availability, maintainability } \\ \text { SST } & \text { Single-Shell Tank } \\ \text { STCG } & \text { Site Technology Coordinating Group } \\ \text { TFA } & \text { Tank Focus Area } \\ \text { TPA } & \text { Tri-Party Agreement } \\ \text { TWRS } & \text { Tank Waste Remediation System } \\ \text { WHC } & \text { Westinghouse Hanford Company }\end{array}$


HNF-SD-HTI-MAR-001, Rev. 0

This page intentionally left blank. 


\subsection{INTRODUCTION}

\subsection{PURPOSE}

This mission analysis report for the Hanford Tanks Initiative (HTI) supports the Hanford Site's Single-Shell Tank (SST) Waste Retrieval Program in its commitment to remove waste from the SSTs for treatment and final closure of the tanks. ${ }^{1}$

The results of the HTI will support the U.S. Department of Energy's (DOE) privatization of retrieval efforts. This report addresses the HTI problem statement:

Alternative technologies to past practice sluicing (PPS) have not yet been demonstrated to remove the hard heel from a sluiced tank or to remove waste from a leaking SST. Nor have performance-based criteria for cleanout and closure been demonstrated to the degree necessary to validate them as "technically and economically achievable".

This report also defines the mission statement and mission boundaries; the known interfaces, both programmatic and project; the mission level requirements; the test and evaluation methodology; and measures of success.

\subsection{SCOPE}

\subsubsection{Scope of the Hanford Tanks Initiative}

Single-shell tank waste retrieval, waste characterization, and tank closure technology needs have recently been confirmed as the highest priority needs by the Site Technology Coordinating Group (STCG) at Hanford. The objectives of the HTI are to accomplish the following:

- Determine the limits of technology for hard heel waste retrieval to the extent that is "technically and economically practical."

- Determine the limits of technology for retrieving the wastes from a leaking tank to the extent that is "technically and economically practical."

- Define performance measures upon which waste retrieval specifications and closure criteria will be based.

- Demonstrate techniques to define and measure retrieval performance objectives and assess compliance with these objectives.

This report is prepared in accordance with the TWRS System Engineering Manual, WHC-IP-1231, Rev. 0, Section 1.0, Mission Analysis dated 04/25/96 (WHC 1995a). 
- Demonstrate integration of EM-50 technologies into baseline TWRS projects.

HTI intends to utilize innovative management approaches to deploy new technologies in the field.

\subsection{BACKGROUND}

\subsubsection{Waste Retrieval Background}

The U.S. Department of Energy (DOE) established the Tank Waste Remediation System (TWRS) Program to manage and immobilize for disposal the waste contained in underground storage tanks at the Hanford Site. The mission of the Tank Waste Remediation System (TWRS) Program is to store, treat, and immobilize highly radioactive tank waste in an environmentally sound, safe, and cost-effective manner (WHC 1995c). The Waste Retrieval Project has as its primary objective, the removal of wastes from, and establish closure criteria of, the DSTs, SSTs, and Miscellaneous Underground Storage Tanks.

From the TWRS's mission statement, a description of the top-level function were functionally decomposed in subsequent applications of the Functions \& Requirements (F\&R) Analysis. HTI demonstration will provide feed-back information (i.e., retrieval performance requirements/constraints, closure basis, and etc.) to the TWRS mission function. The TWRS's mission functions applicable to HTI are 4.2.2.1, and 4.2.4.3 (WHCd 1995). The following functional definitions describe the activities of HTI:

4.2.2.1 Retrieve SST Waste. The removal of wastes (i.e., saltcake, sludge, in-tank hardware, and discrete sources) from single shell tanks (SSTs) and the transfer of these wastes to the Store In-Process Waste function. Wastes will be removed to the extent required for turnover of the tanks to closure.

4.2.4.3 Close Operable Units. Closure ready tanks are deactivated and the operable units are close per applicable regulations. The Operable Units include the tanks, ancillary equipment, and Past Practice Units (PPU), as defined in the Hanford Federal Facility Agreement and Consent Order.

Implementation of the TWRS program strategy will be a phased approach using an alternate acquisition process (privatization) by competitive procurement of private sector contractors that is consistent with the decision that ultimately result from the TWRS Environmental Impact Statement (EIS) and its supplements.

The TWRS privatization will be implemented in two phases using private sector contractors. Phase I privatization will demonstrate on small scale, the contractors' ability to immobilize various waste types. Phase II privatization will involve full scale operations to retrieve and immobilize the remaining wastes from all DSTs and SSTs. HTI is an important element of demonstrating the ability to use private sector technology and contractors for TWRS. 
Figure 1-1 shows how the HTI and other Waste Retrieval projects will support TWRS privatization strategy by feeding back to the TWRS functions information (i.e., performance requirements, constraints, and etc.) for both retrieval and closure basis. The concept of the Waste Retrieval projects are that by demonstrating the limit of technology a feasible retrieval criteria can be formulated to both support privatization, and satisfy the TPA M-45-00 milestones.

\subsubsection{HTI Demonstration Tank Background}

The HTI candidate tanks are 241-C-106, and 241-AX-104. Because of the TPA milestone M-45-00, and other associated projects (i.e., Project W-320), the HTI candidates tanks were selected based on the nature of previous projects' scope and the transition of HTI scope. The actual tank selection is to be determined; see section 1.4.1, Enabling Assumptions. The following is a historical background for the candidate tanks.: 241-C-106, and 241-AX-104.

Tank 241-C-106 is a 530,000-gallon-capacity SST located in the C-Tank Farm in the 200 East Area of the Hanford Site and has been used for radioactive waste storage since 1947. Between mid-1963 and mid-1969, Tank 241-C-106 received high-heat waste, including neutralized Plutonium Uranium Extraction (PUREX) high-level waste and strontium-bearing solids from the strontium and cesium recovery program. In 1971, temperatures in excess of $99^{\circ} \mathrm{C}\left(210^{\circ} \mathrm{F}\right)$ were observed in the tank. To prevent the sludge from drying out and the tank from overheating, approximately 6,000 gallons of cooling water are added to the tank each month. Tank 241-C-106 was withdrawn from active service in 1979 and is categorized as sound (i.e., not known to be leaking). The heat generation rate of the waste in the tank is currently $110,000 \mathrm{Btu} /$ hour and the waste level is approximately 83 inches (Brevick 1995). 
HNF-SD-HTI-MAR-001, Rev. 0

Figure 1-1. Components of the Retrieval Demonstration that Define the Limits of Technology.

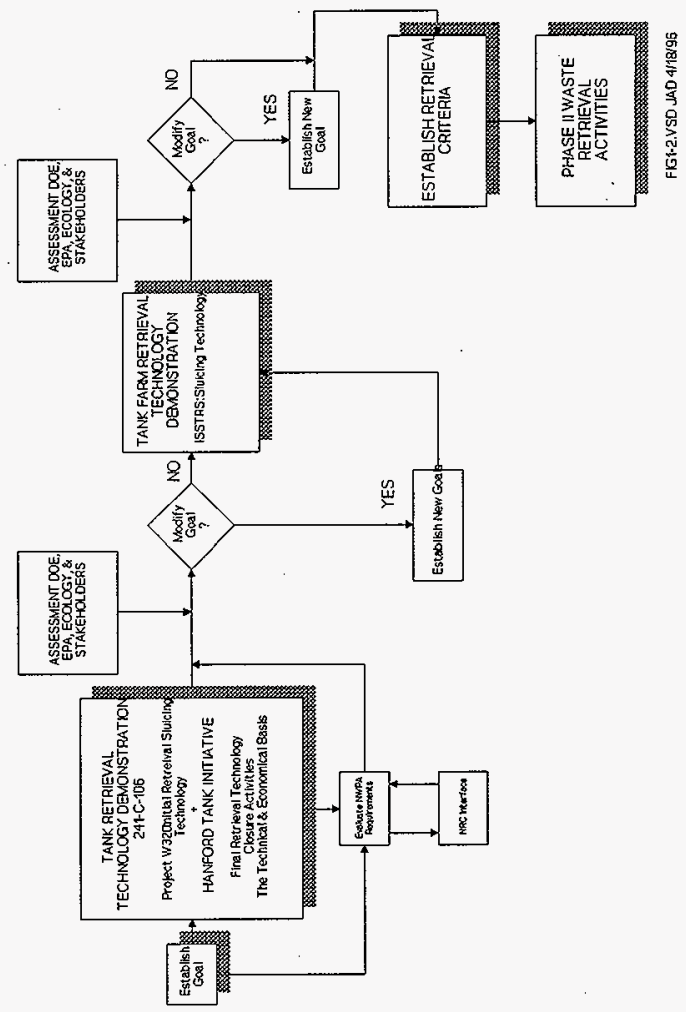


The high heat waste of Tank 241-C-106 has been identified as a Priority One Safety Issue (WHC 1995b) and the planned resolution is to remove enough waste to reduce the tank heat load to less than 40,000 Btu/hour (Wagoner 1995). It is estimated that this can be achieved by removing 170,000 gallons of soft sludge. Project W-320, Tank 241-C-106 Sluicing, is presently in construction to remove this soft sludge utilizing past practice sluicing. However, sluicing is not expected to dislodge and remove the bottom 18" - 24" layer of the tank waste which consists of a hard heel.Tank $241-\mathrm{AX}-104$ is a 1 million gallon SST located in the AX Tank Farm in the 200 East Area of the Hanford Site. It was in operation for storage of radioactive waste, and for support of strontium recovery operations, between 1966 and 1976 . Tank 241-AX-104 was used for storage of PUREX low-level and high-level waste, PUREX organic and inorganic wash waste, B-Plant high-level waste (strontium recovery), and supernatant containing PUREX high-level and sludge supernatant waste from 241-A and AX tanks and 244-AR-002 Tank. Tank 241-AX-104 was categorized as having "questionable integrity" in November 1977 based on leak detection dry well activity measurements. Tank 241-AX-104 is reported to contain 7,000 gallons of sludge, and is currently categorized as an "assumed leaker." Accordingly, 241-AX-104 is considered to represent an example of an SST that has been successfully sluiced to the point where it may approximate the waste retrieval target of 360 cubic feet for a 100-Series tank specified in TPA Milestone M-45-00.

\subsection{JUSTIFICATION}

During Phase I of TWRS Privatization strategy, the M\&I contractor is responsible for tank waste retrieval. Phase I shall include the DST retrieval to provide the waste feed stream for tank waste treatment . Tank retrieval, including SSTs, is to be included in the Privatization strategy for Phase II. The HTI shall provide the private sector the confidence to bid for the following work and ability to acquire financing. Single-shell tank waste retrieval is one of the technically challenging aspects of the program. Single-Shell Tank retrieval, waste characterization and tank closure technology needs have recently been confirmed as the highest priority Hanford tank technology needs by the STCG.

Specifically, removal of the waste heel remaining in 241-C-106 will accomplish two TPA milestones, demonstrate the ability to achieve a retrieval goal of $99 \%$ of the waste volume from a tank, and will achieve actual progress on the retrieval program by emptying one of the 177 tanks.

A total of 12.6 million gallons of waste currently resides in 67 SSTs which are suspected or known to have leaked. An additional concern is the potential for tanks to become leakers during retrieval. It is necessary to demonstrate the limits of technology for retrieving the waste from a leaker to the extent that is "technically and economically practical." It is also necessary to establish leak detection, monitoring, and mitigation criteria and to demonstrate the capability to perform retrieval within those parameters.

The criteria development portion of the Tank 19 closure demonstration at Savannah River will be used to develop the retrieval objectives at Hanford. However, there are likely to be significant differences between arid sites, like Hanford, and wet sites, like Savannah River, relative to functions of the tank closure system and the modeling approach used to assess 
performance.

A tank closure demonstration at Hanford is needed to supplement the Tank 19 closure demonstration at Savannah River in the following specific areas relevant for an arid site:

- Modeling contaminant transport through a vadose zone several tens of meters in thickness, as a basis for evaluating performance;

- Establishing performance requirements for surface barriers, to limit recharge;

- Establishing hydraulic performance requirements of tank fill material to limit leaching of contaminants from residual waste; and

- Establishing structural requirements of tank fill material to prevent tank dome subsidence and resulting degradation of a surface barrier (Wagoner 1995).

\subsubsection{Enabling Assumptions}

The HTI enabling assumptions are stated below. Both assumptions are issues that will require a formal decision and/or decision analysis.

The first assumption is that Tank 241-C-106 and 241-AX-104 shall be used as the HTI demonstration tanks. Specifically, each tank shall demonstrate the following:

- The retrieval demonstration tank is 241-C-106; and

- The post-retrieval, closure readiness demonstration tank is 241-AX-104.

The HTI candidate tanks, 241-C-106, and 241-AX-104 were chosen because of the TPA milestone M-45-00, and other associated projects (i.e., Project W-320). These tanks were selected based on the nature of previous projects' scope and the transition of HTI scope.

The second assumption is that the receiver tank for the retrieval and closure readiness demonstration shall be tank 241-AY-102.

Therefore, both tanks are referenced through out the document as models for the HTI demonstration. 


\subsection{MISSION ANALYSIS}

\subsection{STAKEHOLDERS}

The stakeholders, customers, concerns and values contributes as a role in the mission analysis. HTI's customer is DOE, EPA, and Ecology who have entered into the Tri-Party Agreement and DOE with respect to the privatization effort. The customer needs are translated into requirements; specifically, the needs are to satisfy the TPA milestone requirements. With regards to privatization, DOE's customer need is to offset the risk associated with the Phase II privatization bid process by demonstrating the limit of technology. The stakeholders values factor directly into the decision-making process. Any HTI strategic decisions on cleanup goals, technical decisions on the selection of process equipment have a potential consequence on terms of risk to workers, the public, the environment, economic development and cost.

Therefore, the decision-making process will incorporates the public concerns and values. The values provide a set of guidelines by which individuals, groups, or organizations approach decisions. The stakeholder groups vary in size and interest (WHC 1995c). They include:

- Public Action Groups - the Hanford Advisory Board and Native American Indian Tribes, Site Technology Coordination Group (STCG), and Community Leaders Network (CLN)

- Federal Bodies - The U.S. Department of Energy (DOE), U.S. Environmental Protection Agency (EPA), and Nuclear Regulatory Commission (NRC), and

- State Bodies - Washington State Department of Ecology (Ecology), and the Washington State Department of Health (DOH).

Listed below are nine of the twenty-three stakeholder values found in Appendix A of the Tank Waste Remediation System Mission Analysis (WHC 1995c). This representative subset of stakeholder values will be used to define the TWRS mission objectives and customer needs:

- Protect Public and Worker Health and Safety

- $\quad$ Protect the Environment

- Protect the Columbia River

- A Cleanup to the Level Necessary to Enable Future Options to Occur

- Capture Economic Development Opportunities Locally

- Ensure Compliance 
- Reduce Costs

- Enhance Technology Development

- Protect Rights of the Native American Indians

- Get on with the Cleanup to Achieve Substantive Progress in a Timely Manner

The HTI's contribution to the TWRS's mission objectives is to assist in meeting the stakeholder values listed above.

\subsection{PROBLEM DEFINITION}

Systems and equipment to practically and economically remove the waste within the constraints of the SST system to the levels required by the TPA have not been demonstrated, with the exception of past practice sluicing. This technology will not retrieve a significant amount of "non-sluicable" waste and is not considered acceptable to use in tanks that are known or suspected leakers.

The constraints of the SST system include:

- Retrieving a variety of waste forms with differing chemical and physical properties;

- Reducing the potential of release of hazardous material into the environment; and

- Retrieving in the presence of in-tank hardware.

The overall productivity of retrieval systems requires quantification, which can only be done through actual demonstrations. Previous past practice sluicing campaigns have experienced a significant drop in productivity as the current TPA cleanout levels are approached and retrieval of "non-sluiceable" waste has not been demonstrated under actual tank conditions.

Demonstration of systems to accurately assess, both quantity and chemical constituents, in-tank residual waste to current TPA requirements has not been demonstrated on a production scale for the unstructured environment that will exist within the SSTs.

For final closure, the specific performance assessment modeling and methods of stabilizing emptied SSTs have not been completely developed nor concurred to by the regulators. Additionally, the regulatory and stakeholder process introduces uncertainty to cost, scope, and schedule or engineering activities.

The current TPA prescribes an interim waste retrieval goal that specifies the maximum residual waste to remain after retrieval. This level is based on a $99 \%$ volume reduction and does not reflect either the relative hazard of the waste or other residual waste that might remain from such items as leakage, other tank farm equipment, etc. 


\subsection{INITIAL UNACCEPTABLE STATE}

The present programmatic conditions are:

- $\quad$ SSTs contain waste which is required to be retrieved.

- There is not a qualified retrieval technology identified in the event that PPS does not retrieve sufficient amounts of waste.

- Technologies have not been determined for expanding the capabilities of PPS.

- A clear understanding of closure acceptance criteria has not been established with regulators. Also, processes for closure have not been demonstrated.

- Current TWRS draft EIS does not include closure as part of its scope.

\subsection{FINAL ACCEPTABLE STATE}

The final acceptable end state of HTI is to:

- Have demonstrated the capabilities and effectiveness of retrieval and closure technologies.

- Ensure that technologies have been demonstrated for retrieval and assessment of closure readiness.

- Have provided information to support tank closure evaluation of technologies supporting Phase II privatization.

\subsection{SYSTEM BOUNDARIES AND EXTERNAL INTERFACES}

\subsubsection{System Boundaries and External Interfaces}

The HTI mission has two project components: 1) retrieval technology and performance objectives and 2) closure basis. Both will be implemented separately during the early phases of the project and brought together to complete the mission.

\subsubsection{Physical Interface Boundaries}


HNF-SD-HTI-MAR-001, Rev. 0

The preliminary retrieval physical external interface boundaries are as follows:

- A DST for storage of waste plus all supporting operational systems

- Utilities to support the retrieval operation in the selected Tank Farm

- Solid and liquid waste disposal

- Selected tank farm clean, controlled and stable condition

To provide a complete retrieval system, many boundaries exist within the HTI retrieval system. Examples of these are depicted, along with the external interfaces, in Figure 2-1. 
HNF-SD-HTI-MAR-001, Rev, 0

Figure 2-1. Tank 241-C-106 Heel Retrieval Systems and Physical Boundaries. 


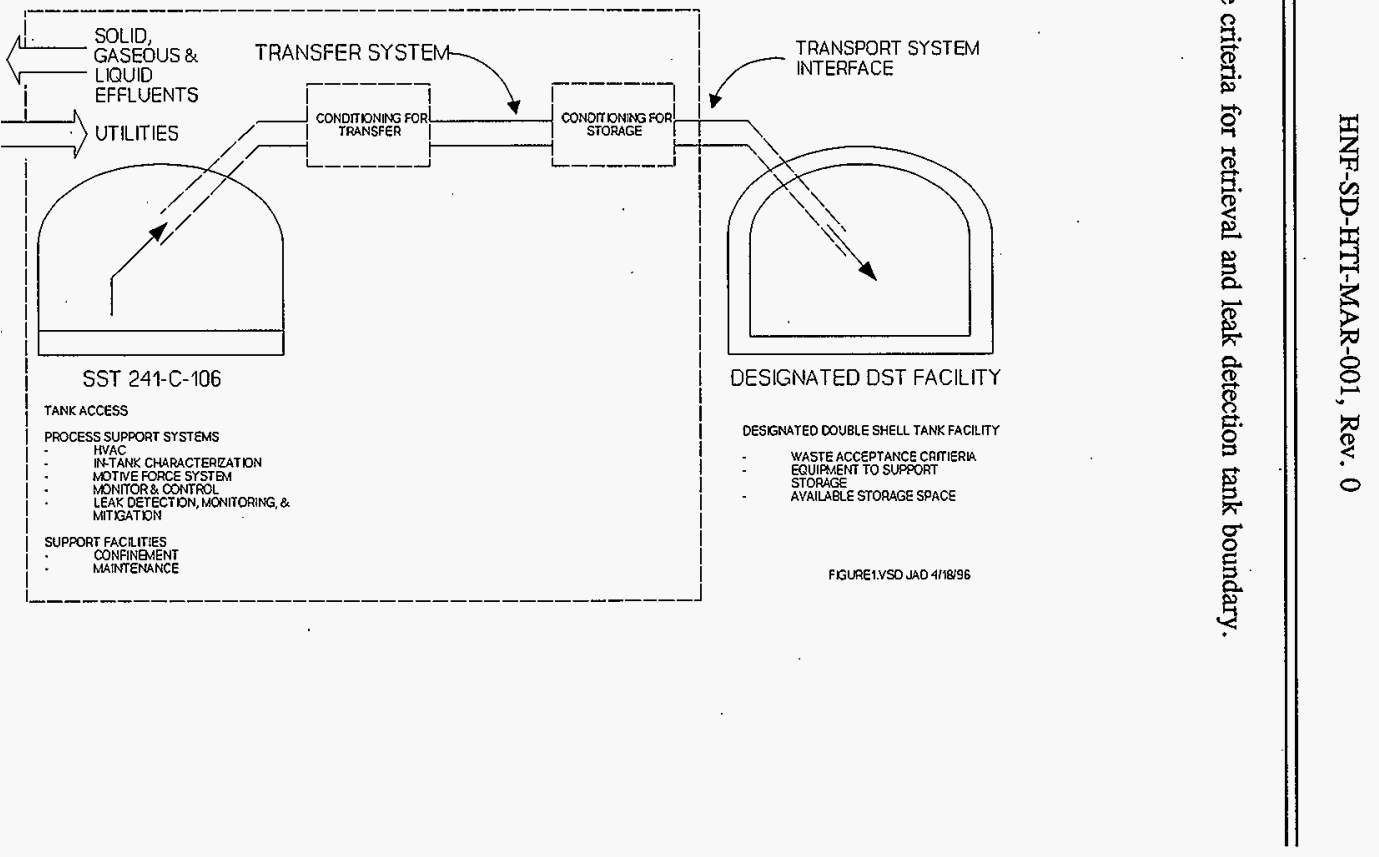


- The DST Waste Volume Projections.

- Waste within tank (not only extended to surrounding soils).

- All other.interfaces are assumed to be internal to the HTI retrieval project.

The preliminary Closure basis physical external interface boundaries are as follows:

- An in-tank surveillance and sampling system to characterize the remaining waste inventory following retrieval

- Utilities to support the characterization effort

- Solid and liquid waste disposal

- Selected tank farm clean, controlled, and stable condition

To provide a complete characterization system, boundaries exist within the HTI characterization system. Examples of these are:

- Access to HTI candidate tank (i.e., Tank 241-104-AX)

- Complete Characterization system (with the light duty utility arm being the prime candidate) including:

- Complete confinement and all operational support systems, and

- Appropriate internal tank surface mapping and sampling equipment.

The HTI mission organizational boundaries are as follows:

- Quality Assurance

- Tank Farm Operations

- TWRS and Retrieval Project Office

- Safety

- Environmental

- DOE--RL

- STCG, TFA

- National Laboratories 


\section{- Stakeholders}

Programmatic task constraints include the following:

- Schedule

- Funding limitations

- Regulatory and the formal project planning/implementation system

- TWRS storage/infrastructure support

\subsection{MISSION STATEMENT, NEEDS, GOALS, AND OBJECTIVES}

\subsubsection{Mission Statement}

By December 2000, using the HTI candidate tanks 241-C-106 and 241-AX-104, demonstrate the technologies, and processes that will be used for the following criteria:

- Retrieve difficult to remove SST hard heel wastes,

- Retrieve waste from a leaking SST (i.e., planned for cold-test evaluation);

- Establish retrieval performance evaluation criteria;

- Demonstrate technologies that measure compliance with retrieval performance evaluation criteria; and

- Provide a basis for future NEPA, safety, and regulatory actions affecting waste retrieval and operable unit closure for tank farms.

\subsubsection{Mission Needs}

There is insufficient criteria and lack of demonstrated technology and processes to close tank farms resulting in high programmatic risk.

Specifically:

- Regulatory and stakeholder process for closure introduces uncertainty to cost, scope, and schedule of engineering activities

- Lack of demonstrated performance-based criteria for clean out of tanks

- Have not demonstrated capability for retrieving waste from tanks 


\subsubsection{Mission Goals and Objectives}

The HTI goals and programmatic/technical objectives are identified in Table 2-1.

Table 2-1. Hanford Tanks Initiative Goals and Objectives. (3 sheets)

\begin{tabular}{|c|c|}
\hline 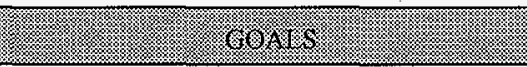 & 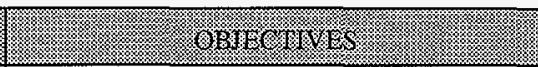 \\
\hline $\begin{array}{l}\text { Successfully demonstrate technology(ies) that } \\
\text { provide expanded capabilities beyond Past } \\
\text { Practice Sluicing and are extended to } \\
\text { retrieve waste from other SSTs. }\end{array}$ & $\begin{array}{l}\text { PROGRAMMATIC OBJECTIVES: } \\
\text { Complete Hanford Tanks Initiative project } \\
\text { within four years. } \\
\text { Demonstrate the methods and effort required } \\
\text { to characterize and remove waste to the } \\
\text { extent "technically and economically } \\
\text { practical." Relative to the amount of risk } \\
\text { reduction achieved, document performance, } \\
\text { cost, and risk tradeoff as a basis for } \\
\text { determining how much waste needs to be } \\
\text { removed to recommend for tank closure. } \\
\text { Provide technical baseline information on } \\
\text { SST retrieval and closure to reduce } \\
\text { programmatic risk associated with Phase II } \\
\text { privatization. } \\
\text { Support goals of privatization. } \\
\text { Involve the private sector in the } \\
\text { demonstration so that they can acquire } \\
\text { experience and understanding in retrieving } \\
\text { waste from the SSTs. } \\
\text { Utilize EM-50 funds for selecting the best } \\
\text { available commercial technology by } \\
\text { allowing two demonstrations of competing } \\
\text { technologies. }\end{array}$ \\
\hline & $\begin{array}{l}\text { TECHNICAL OBJECTIVES: } \\
\text { Demonstrate the technologies and evaluate } \\
\text { the cost required to remove waste from a } \\
\text { potentially leaking (or leaking) SST to the } \\
\text { extent needed for closure. } \\
\text { Develop acquisition strategies to optimize } \\
\text { the use of outside resources and skills. }\end{array}$ \\
\hline
\end{tabular}




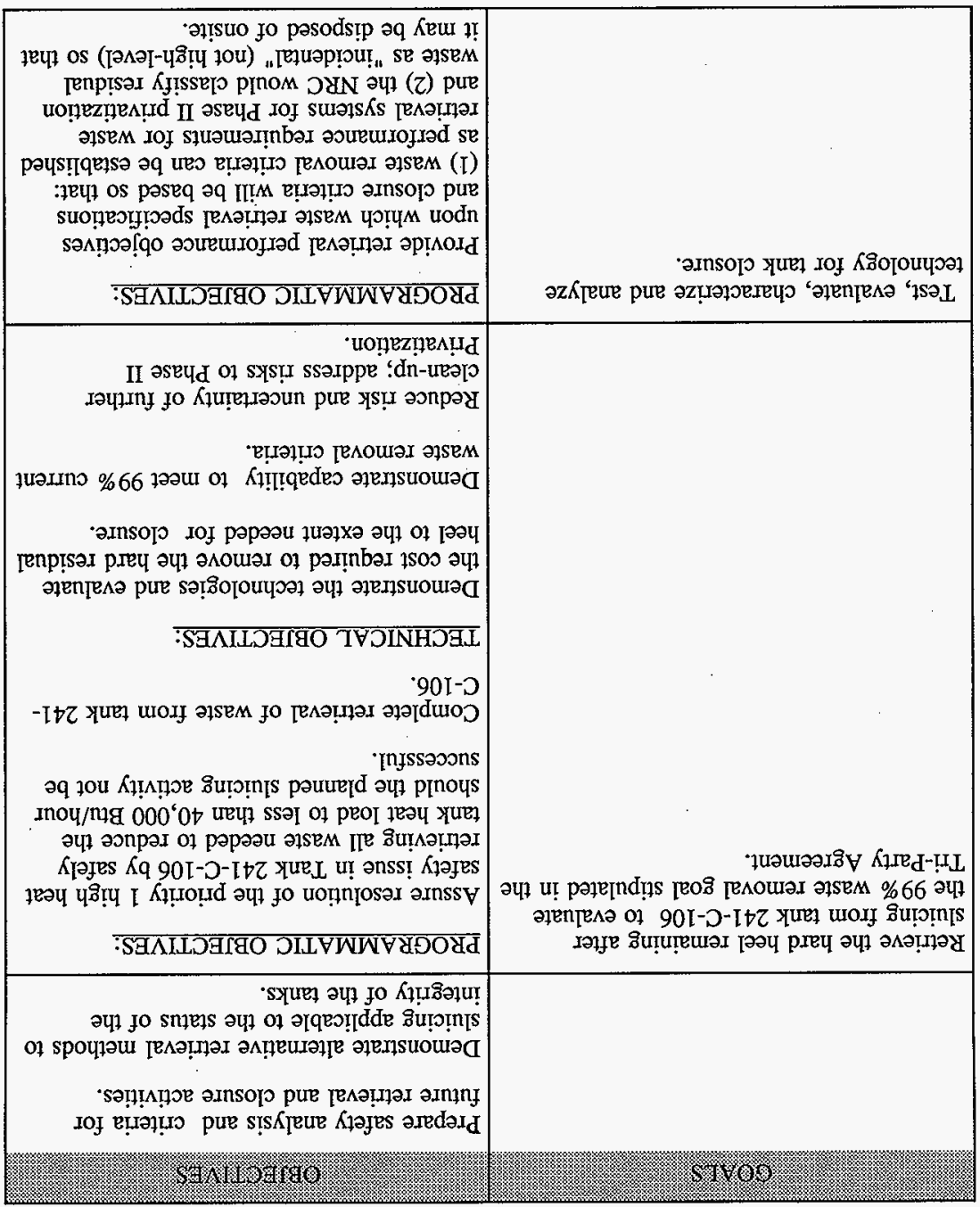

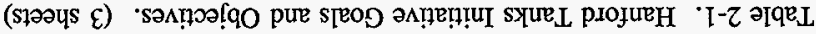


Table 2-1. Hanford Tanks Initiative Goals and Objectives. (3 sheets)

\begin{tabular}{|c|c|}
\hline $\begin{array}{l}\text { Select best available commercial technology } \\
\text { for assessing readiness for tank closure. }\end{array}$ & $\begin{array}{l}\text { PROGRAMMATIC OBIECTIVES Cont'd: } \\
\text { Work with regulators and stakeholders to } \\
\text { establish an acceptable decision framework, } \\
\text { methods, and data for articulating } \\
\text { performance, cost, risk, and safety tradeoff } \\
\text { in support of closure criteria. } \\
\text { TECHNICAL OBJECTIVES: } \\
\text { Develop and demonstrate an approach for } \\
\text { assessing readiness to close tank farms with } \\
\text { residual waste at an arid site, including } \\
\text { supporting risk assessment and structural } \\
\text { analysis. Learn from tank closure } \\
\text { demonstrations at other sites. } \\
\text { Demonstrate technologies for sampling and } \\
\text { characterization of residual waste. } \\
\text { Demonstrate capability to quantify residual } \\
\text { waste volume. } \\
\text { Reduce risk and uncertainty of further } \\
\text { clean-up; address risks to Phase II } \\
\text { privatization. }\end{array}$ \\
\hline
\end{tabular}

\subsection{MISSION LEVEL REQUIREMENTS}

Referenced in Appendix B is the TPA Change Form M-45-00 and this is the key requirement applicable and drives the HTI mission. The TWRS strategy is designed to meet the following milestones negotiated in the Hanford Federal Facility Agreement and Consent Order or the Tri-party Agreement (TPA) (Ecology et al. 1994). To comply with internal requirements, the HTI Retrieval and Closure project will test and evaluate to supply data per the M-45-00 TPA milestone to the TWRS mission. The TPA milestone, M-45-00 describes tank closure readiness that follows the retrieval activities. The requirement states:

- M-45-00 Complete Closure of all Single Shell Tank Farms

Closure will follow retrieval of as much tank waste as technically possible, with tank 
Ecology explanation as to why these levels cannot be achieved, and specifying the quantities of waste that the DOE propose to leave in the tank. The request will be approved or disapproved by EPA and Ecology on a tank-by-tank basis. Procedures for modifying the retrieval criteria listed above, and for processing waiver requests are outlined in the Appendix to this change request.

All parties recognize that the reclassification of previously identified RCRA past practice units to ancillary equipment associated with the TSD unit is strictly for application of a consistent closure approach. Upgrades to previously classified RCRA past practice units to achieve compliance with RCRA or dangerous waste interim status technical standards for tank systems (i.e., secondary containment, integrity assessments, and etc.) will not be made mandated as a result of this action.

However, any equipment modified or replaced will meet interim status standards. In evaluating closure options for Single-Shell Tanks, contaminated soil, and ancillary equipment, ecology and EPA will consider cost, technical practicability, and potential exposure to radiation. Closure of all units within the boundary of a given tank farm will be addressed in a closure plan for the single-shell tanks.

The HTI mission is further developed by the lower level milestones listed below (i.e., requirements/constraints).

- M-45-01: Develop Single-shell Tank (SST) Retrieval Technology

- M-45-02: Submit annual updates to SST Retrieval Sequence

- M-45-03: Complete SST Waste Retrieval Demonstration

$9 / 30 / 2002$

- M-45-04: Provide Initial Single-Shell Tank Retrieval System

- M-45-05: Retrieve Waste form all Remaining Single-Shell Tanks

- M-45-06: Complete Closure of all Single-Shell Tank farms.

The HTI top-level function are derived from these milestone requirements/constraints and listed below:

- Demonstrate the range of retrieval technologies;

- Identify SST waste retrieval technologies - Cold Demonstration;

- Determine SST waste retrieval technologies - Hot Demonstration;

- $\quad$ Evaluate concepts \& perform tests;

- Compile transfer information;

- Define retrieval completion criteria; and 
- Compile transfer information;

- Define retrieval completion criteria; and

- Establish Closure Basis;

The applicable external requirements that the HTI Retrieval project will satisfy are listed in Appendix C. This requirements list includes those applicable requirements from function 4.2.2.1, and 4.2.4.3.

\subsection{TEST AND EVALUATION ANALYSES}

Key areas to consider for HTI Retrieval and Closure test and evaluation are listed below: Retrieval Technology

- Retrieval effectiveness;

- System performance, i.e., reliability, availability, maintainability (RAM);

- Leakage control and detection;

- Waste transfer operational parameters;

- Retrieval rate that the system can sustain, both gross removal and final clean-up; and

- Tank physical conditions

- Tanks contain a wide variety of waste forms

- Tanks contain a range of waste quantities

- Tank waste is intermixed with in-tank hardware

- Known assumed and potential leaking tanks exist.

Closure Basis

- Develop retrieval performance objectives;

- Characterization of remaining waste;

- Transport Modeling;

- Risk Assessment;

- Performance Assessments and Alternatives; and

- Evaluate Closure Performance and Alternatives; 


\subsection{TECHNICAL PERFORMANCES AND MEASURES}

The measure of success for the HTI fall into the categories of management, safety and closure, industry, operations, and other key success factors:

Management

- Integrated $\mathrm{HQ} /$ Field objectives and approach for implementation;

- Congressional support for EM Budget;

- Stakeholder/Regulator sustained participation;

- Demonstrate "new methods' for creative involvement of stakeholders and regulators to effectively and efficiently complete demonstrations; and

- Establish and execute a credible baseline.

Safety and Closure

- Establish connection between closure (residual waste left in tank) to NRC incidental waste determination;

- Obtain sufficient "cleản tank" information to support closure decision making;

- Establish a safety basis for waste retrieval of SSTs; and

- Establish interface with overall closure planning to integrate demonstration data with that work.

Industry

- Involvement of private industry to validate and provide the technical and economical "best value to government" industry technologies; and

- Provide sufficient data to establish cost, and schedule basis for private vendors to bid Phase II privatization.

Operations

- Establish requirement traceability matrix to validate and verify compliance with the regulatory requirements and constraints; and

- Adopt a practical conduct of operations to support efficient introduction of new technologies/equipment into the tank and integrate into broader program. 
Other

- Early completion of M-45-03 milestone (SST Waste Retrieval Demonstration).

\subsection{SYSTEM LIFE CYCLE}

The HTI Retrieval and Closure project life cycle begins with approval of the Mission Analysis and is completed, for the retrieval portion when the systems developed to retrieve the waste making up the heel in tank 241-106-C have reached their "technically and economically practical" limit. Specific criteria to measure this will be developed during the design and permitting phase of the project and will be concurred with by affected regulators with input by stakeholders. In addition to this, the waste will have been safely transferred and stored in a DST and the tank farm infrastructure returned to a controlled, clean and stable condition.

For the closure basis portion, completion is defined as characterizing an inventory of waste remaining in the assumed candidate tank: $241-104-\mathrm{AX}$, and performance assessment that evaluates closure of 241-104-AX. 
HNF-SD-HTI-MAR-001, Rev. 0

This page intentionally left blank. 


\subsection{REFERENCES}

DOE, 1995, Systems Engineering_Standard, DOE/RL-95-12, Rev. AE Draft

Brevick, C. H., 1995, Historical Tank Content Estimate for the Northwest Quadrant of the Hanford 200 East Area, WHC-SD-WM-ER-349, Westinghouse Hanford Company, Richland, Washington.

Ecology, EPA, and DOE, 1994, Hanford Federal Facility Agreement and Consent Order, as amended, Washington State Department of Ecology, U.S. Environmental Protection Agency, and U.S. Department of Energy, Olympia, Washington.

Hanlon, B.M., 1995, Waste Tank Summary Report for Month Ending June 30, 1995, ,WHC-EP-0182-87, Westinghouse Hanford Company, Richland, Washington.

HTI, 1995, Conceptual Proposal for Hanford Waste Technology Demonstration Project, Draft, Westinghouse Hanford Company, Richland, Washington.

Johnson, M.E., 1995, Tank Waste Remediation System, Baseline System Description, WHC-EP-0856, Rev. 1, DRAFT, September 1995 draft (to be revised and issued).

Resource Conservation and Recovery Act of 1976, 42 USC 6901, et seq.

Wagoner, J.D., 1995, [Transmittal of "Conceptual Proposal to Conduct a Hanford Waste Tank Technology Demonstration Project"], (letter to S.P. Cowan, Deputy Assistant Secretary for Waste Management, EM-30/HQ, December 10,) U.S. Department of Energy, Washington, D.C.

WHC, 1995a, WHC Tank Waste Remediation System Systems Engineering Manual, Mission Analysis (Interim), WHC-IP-TSEP-01, Rev. 0, August 1995, Westinghouse Hanford Company, Richland Washington.

WHC, 1995b, Status Report on Resolution of Waste Tank Safety Issues at the Hanford Site, WHC-EP-0600, Westinghouse Hanford Company, Richland, Washington.

WHC, 1995c, Tank Waste Remediation System Mission Analysis, WHC-SD-WM-MAR-008, Rev. 0, September 1995, Westinghouse Hanford Company, Richland Washington.

WHC, 1995d, Tank Waste Remediation System Functions \& Requirements, WHC-SD-WM-FRD-020, Rev. 0, Draft, March 1996, Westinghouse Hanford Company, Richland Washington. 
APPENDIX A

Definitions

A-1 
Boundary

Constraints

Disposal

Enabling Assumptions

Function

Goals

Interface

Interface Requirement

Issues

Measure of Success

Objectives

Problem statement

Program

Remediation

Remediation System

Requirement
The border that establishes the interface for inputs and outputs of the system.

Restrictions or limitations that must be met.

Placement of waste in such a manner that ensures isolation from the environment.

When issues are unresolved, some enabling assumptions are made as to the likely resolution of the issue in order to allow further decomposition of the functions and the definition of requirements. Eventually, every enabling assumption must be a formal decision.

A specific action, activity, or process that achieves or supports the achievement of an objective. An operation that must be performed to accomplish the mission.

Statements describing the desired endpoints.

System boundary across which material, data, or energy pass.

Requirements that are defined at the system boundary across which material, data or energy passes.

Issues refers to those critical issues and decisions identified in the TWRS database, and this document that must be addressed and resolved.

A set of attributes that, when compared to actual results, shows how well the mission was accomplished.

Discrete, measurable events that, if accomplished, will contribute to achieving a goal.

A declaration of needs and desired outcomes.

An organized set of activities directed toward a common purpose. Programs typically comprise technology-based activities, projects, and supporting operations.

Action taken to safely store, maintain, treat, and dispose of waste.

An integrated solution for carrying out the specific functions associated with remediating tank waste.

Describes either quantitatively, or qualitatively, the needs of a function. 
Risk

Strategy

System

Task

Test Plan

Tri-Party Agreement
Health and safety or environmental issues that may adversely impact the program's ability to meet regulatory requirements or accomplish program goals.

A plan or approach to accomplish the mission.

A combination of related functions, processes, people, and end items integrated into a single activity.

A unique effort within a program that has a firmly scheduled beginning, intermediate, and ending date milestone.

The Test Plan is a document captures the detailed information for the conduct or execution of a Test Scenario; the WHEN, WHO, WHERE, and HOW WELL. It functions as the 'specification' for the testing activity.

Washington State Department of Ecology, U.S. Environmental Protection Agency, and U.S. Department of Energy, 1992, Hanford Federal Facility Agreement and Consent Order, 2 vols., as amended. 


\section{APPENDIX B \\ Attachment 1, TPA Change Form M-45-93-01, Approved 1/25/94 \\ Process for Determining the Limit of \\ Technology for SST Retrieval}


HNF-SD-HTI-MAR-001, Rev. 0

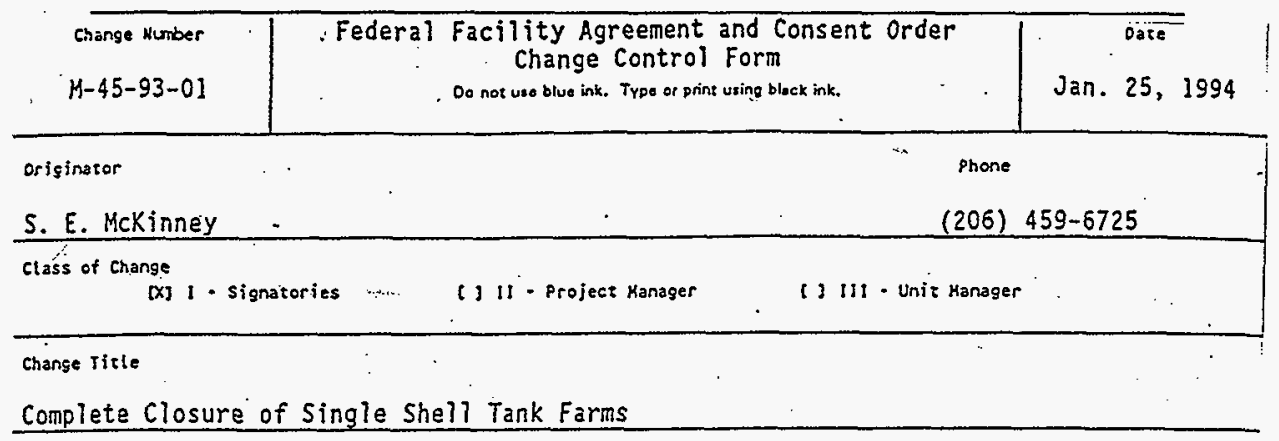

Description/Justification of Change

Establish the following milestones and targets.

M-45-00 Complete closure of all single shell tank farms.

September 2024

Closure will follow retrieval of as much tank waste as technically possibie, with tank waste residues not to exceed 360 cubic feet (cu: ft.) in each of the 100 series tanks, $30 \mathrm{cu}$. ft. in each of the 200 series tanks, or the limit of waste retrieval technology capability, whichever is less. If the DOE believes that waste retrieval to these leveis is not possible for a tank, then DOE will submit a detailed explanation to EPA and Ecology explaining why these levels cannot be achieved, and specifying the quantities of waste that the DOE proposes to leave in the tank. The request will be approved or disapproved by EPA and Ecology on a tank-bytank basis. Procedures for modifying the retrieval criteria listed above, and for processing waiver requests are outlined in the appendix to this change request.

(Continued on next page)

Inpact of Change

This change will create a single milestone for retrieyal of single shell tank wastes and closure of the single shell tank farms. It will replace 4 major milestones $(M-06$, $M-07, M-08, M-09)$. It will add retrieval of tank wastes as a formal requirement for single sheil tank closure. The six operable units (tank farms) will be excluded from Milestone $M-13-00, M-15-00$ and $M-16-00$.

Affecied Documents

Hanford Federal Facility Agreement and Consent Order Action PTan, Appendix D

ipprovals . XApiproved . Disapproved

This change forta approved by Amenchent four to the Hainford Foderal facility Agreement and consent order execused by the signatories on January $25,1994$.

John Waooiner

DOE

Gerald Emison

Ë

January 25, 1996

Date

Kary Rivel and

Ecology

January 25, 1996

January 25, 1994

Date

B-2 
Following completion of retrieval, six operable units (tank farms), as described in appendix $C$ (200-BP-7, 200 PO-3, 200-RO-4, 200-TP-5, 200-TP-6, 200-UP-3), will be remediated in accordance with the approved closure plans. Final closure of the operable units (tank farms) shall be defined as regulatory approval of completion of closure actions and commencement of postclosure actions.

For the purposes of this agreement all units located within the boundary of each tank farm will be closed in accordance with WAC 173-303-610. This includes contaminated soil and ancillary equipment that were previously designated as RCRA past practice units. Adopting this approach will ensure efficient use of funding and will reduce potential duplication of effort via application of different regulatory requirements: WAC 173-303-610 for closure of the TSD units and RCRA Section 3004(u) for remediation of RCRA past practice units.

All parties recognize that the reclassification of previously identified RCRA past practice units to ancillary equipment associated with the TSD unit is strictly for application of a consistent closure approach. Upgrades to previously classified RCRA past practice units to achieve compliance with RCRA or dangerous waste interim status technical standards for tank systems (i.e., secondary containment, integrity assessments, etc.) will not be mandated as a result of this action. However, any equipment modified or replaced will meet interim status standards. In evaluating closure options for Single-Shell Tanks, contaminated soil, and ancillary equipment, Ecology and EPA will consider cost, technical practicability, and potential exposure to radiation. Closure of all units within the boundary of a given tank farm will be addressed in a closure plan for the Single-Shell Tanks.

Waste generated from the closure or remediation of formerly designated past practice units (as specified above) will be handled in accordance with regulatory mechanisms and practices available for past practice units.

This milestone will replace the current Milestones M-06 (Develop Single-Shell Tank waste retrieval technology and complete scale model testing), M-07 (Initiate full scale demonstration of waste retrieval technology), M-08 (Initiate full scale tank farm closure demonstration project), and $\mathrm{M}-09$ (Complete closure of all 149 Single-Shell Tanks). Retrieval of all Single-Shell Tank wastes will be incorporated into this milestone. The new milestone will combine retrieval of tank wastes and closure of the tank farms. It is the intent that the closure standards under RCRA TSD Units and Past Practices will be consistent with closure standards under CERCLA operable units for adjacent waste sites.

M-45-01 Develop single-shell tank (SST) retrieval technology September 1994

Develop single-sheli tank waste retrieval technology and complete ścale model testing. Various waste retrieval technologies will be evaluated for retrieving each of the several types of single-shell tank wastes. Emphasis will be placed on optimizing waste removal while minimizing personnel exposure. Promising technologies will be evaluated for each waste type and one or more wijl be selected for testing using simulated waste in a scale model (minimum $1: 12$ scale). tank.

M-45-02 Submit annual updates to SST Retrieval Sequence Document September 2017 
This provides for an annual update of an SST Retrieval Sequence document that will define the tank selection criteria, tank selection rationale, reference retrieval method(s) for each tank, and the estimated retrieval schedules. The annual updates will be submitted to Ecology for approval.

M-45-02A Submit initial SST retrieval sequence document for

September 1996 Ecology approval.

M-45-02B-V Submit annual update of SST retrieval sequence document for Ecology approval.

September 1997

through September 2017

M-45-03-TO1 Complete SST waste retrieval demonstration

September 2003

Initiate and complete a full scaie demonstration of SST retrieval technology. This demonstration will be considered complete when no less than $99 \%$ of the waste inventory is removed from the tank.

M-45-03A Injtiate sluicing retrieval of C-106

October 1997

Initiate sluicing retrieval of tank 241-C-105 to resolve the high-heat safety issue and demonstrate waste retrieval.

M-45-03-T02 Initiate final retrieval demonstration of $C_{-} 106$

June 2002

Initiate final retrieval of tank $241-c-106$ to complete initial

demonstration of SST retrieval technologies.

M-45-04-T01 Provide Initial Single-Shell Tank Retrieyal Systems

November 2003

Complete construction and related testing of the initial SST retrieval systems. This milestone will provide retrieval systems for an entire single-shell tank farm or an equivalent number of tanks.

M-45-04A Complete Conceptual Design for the initial SST

April 1997 retrieval systems.

M-45-04-TO2 Complete design for the initial SST retrieval systems. December 2000

M-45-04-TO3 Complete construction for the initial SST retrieval systems. June 2003

M-45-05 Retrieve waste from all remaining Single-Shell tanks. September 2018

Complete waste retrieval from all remaining single sheli tanks.

Retrieval standards and completion definitions are provided under the major milestone. The schedule reflects retrieval activities on a farm-by-farm basis. It also allows flexibility to retrieve tanks from various farms if desired to support safety issue resolution, pretreatment or disposal feed requirements, or other priorities.

M-45-05-T01 Initiate tank waste retrieval from one.single-shell tank. December 2003

M-45-05-T02 Initiate tank retrieval from two additional single-shell September 2004 tanks. 
M-45-05-103 Initiate tank retrieval from three additional singleshell tanks.

M-45-05-T04 Initiate tank retrieval from four additional singleshell tanks.

September 2005

September 2006

M-45-05-T05 Initiate tank retrieval from five additional singleshell tanks.

M-45-05-T06 Initiate tank retrieval from five additional singleshell tanks.

September 2007

September 2008

M-45-05-T07 Initiate tank retrieval from seven additional singleshell tanks.

September 2009

M-45-05-T08 Initiate tank retrieval from eight additional singleshell tanks.

September 2010

M-45-05-T09 Initiate tank retrieval from ten additional singleshell tanks.

September. 2011

September 2012

M-45-05-T10 Initiate tank retrieval from 12 additional singleshell tanks.

M-45-05-Tll Initiate tank retrieval from 14 additional singleshell tanks.

September 2013

September 2014

M-45-05-T12 Initiate tank retrieval from 17 additional singleshell tanks.

M-45-05-T13 Initiate tank retrieval from 20 additional singleshell tanks.

September 2015

M-45-05-T14 Initiate tank retrieyal from 20 additional singleshell tanks.

September 2016

M-45-05-T15 Initiate tank retrieyal from 20 additional singleshell tanks.

September 2017

M-45-05 Complete closure of all single-shell tank farms

September 2024

The Single-Shell Tank Closure Work $P$ lan will be prepared describing the work integration process for single-shell tank closures and status of work and integration process. Known issues will be identified and an explanation will be given on how these issues are being addressed. This Hork Plan will be provide to Ecology for review/comment and will bé used as a roadmap for closure of the single-shell tanks. Because of the uncertainties in the closure process, the Hork Plan will evolve as these uncertainties are resolved and eventually it will become the SST Closure/Post-Closure Plan(s) issued for Ecology's approval under subsequent TPA interim milestones. Hajor work areas covered in the Hork Plan will include waste retrieval, operable units characterization, technologies development to support closure, regulatory pathway and strategy for achieving closure. 
M-45-06-T01 Submit tank closure/post-closure plan for selected closure demonstration operable unit or tank farm to Ecology for approval.

M-45-06-T02 Ecology will issue final closure/post closure plan for September 2006selected closure demonstration operable unit or tank farm.

M-45-06-T03 Initiate closure actions on an operable unit or tank farm March 2012 basis. Closure shall follow completion of the retrieval actions under proposed milestone M-45-05. Closure will be defined in an approved closure plan for the demonstration farm. Final closure is defined as regulatory approval of completion of closure actions.

M-45-06-T04 Complete closure actions on one operable unit or tank farm. March 2014

14-45-07 Complete Evaluation and Demonstration Testing of Smal] September 1997 Scale Sub-Surface Barriers

DOE will assess the risk to the environment due to tank waste remediation. DOE with concurrence from Ecology and EPA will evaluate barrier technology as a means to minimize those risks and vendor. capabilities to deploy and test barriers in Hanford soils. Retrieval of waste from tank 241-6-106 will proceed without a barrier.

M-45-07A Complete Evaluation of Sub-Surface Barrier Feasibility September 1994

Complete a feasibility study of barriers to accomplish the following:

1) Estimate the potential environmental impact of waste storage and retrievar activities without the application of barriers.

2) Establish functional requirements of barriers to minimize the impact associated with the waste storage and retrieval activities.

3) Evaluate the application of existing sub-surface barrier technologies to meet functional requirements of barriers and the potential reduction in environmental impacts from the application of barriers to SST waste storage and retrieval activities.

M-45-07B Reach Decision on Whether to Proceed with Demonstration January 1995

Based on the results of the sub-surface barrier feasibjlity study, ECology, EPA, and DOE will make a decision on whether to proceed with a sub-scale demonstration. If the decision is negative, then interim milestone M-45-07 will be considered complete.

M-45-07-TO1 Establish Performance Criteria and Test Specifications

March 1995

Ecology, EPA, and DOE establish and reach agreement on performance. criteria and test specifications to be used for the small scale demonstration of sub-surface barrier technologies. 
M-45-07-T02 Initiate Demonstration Testing of Selected Sub-Surface Barrier Technologies

Testing of one or more small scale sub-surface barrier technologies will. be initiated at a hanford test site. Documentation will be completed prior to testing which will incorporate performance criteria and test specifications. Initiation of demonstration is defined as completion of construction and initiation of test procedures.

M-45-07-T03 Complete Evaluation of Sub-Surface Barrier Demonstration Test March 1997 Results

Test data and related information will be provided to Ecology, EPA, and $D O E$ as it becomes available during testing. Sub-surface barrier technologies will be evaluated against the performance criteria and test specifications.

M-45-07-T04 Reach Decision on Whether to Proceed with Sub-Surface Barrier June 1997 Program

Ecology, EPA, and DOE will make a decision on whether to proceed with installation of a full-scale sub-surface barrier to support SST retrieval under milestone $M-45-07$. If the decision is negative, then milestone 1 -45-07 will be considered comptete.

M-45-07C Establish New Milestones for Sub-Surface Barrier Implementation

Ecology, EPA, and DOE will negotiate and reach agreement on new milestones to support milestone $M-45-07$ and a program to install subsurface barriers in SST farms or individual tanks to support SST retrieval schedules under $M-45-00$. New milestones will include completion of construction of a fuil-scale sub-surface barrier in a tank farm, in conjunction with the installation of the retrieval systems pursuant to M-45-04-T03 (complete construction for the initial SST retrieval systems). 


\section{APPENDIX TO CHANGE REQUEST $\mathrm{M}-45-93-01$ \\ Waste Retrieval Criteria Procedure}

Introduction:

The purpose of this procedure is to establish a means to set, evaluate, and revise criteria for determining the allowable residual waste following waste retrieval operations on the Hanford single shell tanks (SST).

The format for this procedure is to progress through a series of steps as depicted in the generic logic diagram displayed as Figure 1. Each step is briefly outlined and includes elements that constitute completion of the step.

Definition of terms specific to Waste Retrieval Activities:

Residual Waste: Tank waste remaining in the tank after all waste retrieval actions have been completed. Some materials may be excluded from residual waste volume calculations, subject to approval in the closure plan.

Step 1: Establish Goal

This initial step establishes the goal (the standard) for waste retrieval percentage and the method to be used to calculate the allowable residual waste volume following completion of retrieval operations. The calculation method is dependent on the variable to be measured (total tank waste inventory), and closure criteria and strategy. The proposed residual waste volume calculation method is shown in Attachment 1. A retrieval goal has. been established as defined in milestone M-45-00.

Step 2 : Evaluate Major Assessment Areas

Once the goal has been estabiished, it is assessed against two major areas, which are:

a) SST Demonstration: Demonstrate achievability of waste- retrieval goal during tank 241-C-106 tank retrieval demonstrations. These demonstrations will include the reference SST retrieval technologies. The effectiveness of the retrieval operation will be determined with a topographical measurement of remaining waste in the tank, and a calculation of waste inventory. The inventory calculation will be based on calculated volume of the tank, waste topography measurements with appropriate surveying techniques, and.include adjustments for any detectable deformities in the tank structure (i.e., liner bulges). This technique will be demonstrated and calibrated in this retrieval demonstration. Prepare input to the retrieval goal evaluation (step 3) to accommodate the retrieval operations and residual measurement demonstrations. 
b) Evaluate requirements of high-level waste (HLW) disposal from DOE Orders and the Nuclear Waste Policy Act (NWPA). Establish an interface with the Nuclear Regulatory Commission (NRC), and reach formal agreement. on the retrieval and closure actions for single shell utanks with respect to allowable waste residuals in the tank and soil column. Prepare input to the retrieval goal evaluation (step 3) to accommodate the agreements on allowable residuals.

Step 3 : Tank Retrieval Demonstration Goal Compliance

Perform a joint assessment by DOE, EPA, and Ecology of the retrieval goal, based on the inputs from Steps 1 and 2. Modify the retrieval goal to match the most restrictive case (i.e., the highest retrieval \% requirement).

Step 4 : Tank Farm Retrieval Demonstration

Perform the Tank Farm Retrieval Demonstration on the selected tank farm or initial set of single-shell tanks to be retrieved. Repeat the residual inventory measurement steps identified in the tank retrieval demonstration. Calculate the residual inventory for each tank, based on the formula and procedure in Attachment 1.

Step 5 : Tank Farm Retrieval Demonstration Goal Compliance

Perform a joint assessment by DOE, EPA, and Ecology of the retrieval goal, based on the tank farm retrieval demonstration results. Modify the goal to match best available technology. Notify NRC as required for compliance with NWPA. Establish formal criteria for retrieval of waste from the remaining SST's. Finalize closure plans for tank farms and obtain. concurrence from regulatory agencies.

Step 6 : SST Retrieval

Proceed with retrieval of waste from the remaining SSTs. The schedule reflects retrieval activities on a tank-by-tank basis. It also allows flexibility to retrieve tanks from various farms if desired to support safety issue resolution, pretreatment or disposal feed requirements, or other priorities. Completion of retrieval will be in accordance with approved closure plans.

Step 7 : Determine Residual Haste Percentage.

The waste residuals are calculated for each tank.

Step 8 : Retrieval Compliance Evaluation

Compare residual waste in each tank with criteria. Document compliance with criteria via notification to appropriate regulatory agencies. If residual complies with criteria, proceed with final closure operations (step 14). If residuals do not comply with criteria, prepare a request for waiver to the appropriate regulatory agency, (step 9): 
Step 9 : Petition for Regulatory Waiver

An assessment is made as to the applicability of petitioning for regulatory waiver. This requires the review of relevant NRC license'issues and possible closure plan modifications. Submit waivers to appropriate regulatory agencies:

Step 10 : Waiver Acceptance

If a waiver is accepted, closure operations for the tank farm is initiated (Step 14). If the wajver is not accepted, additional retrieval operations are required. New technology may be needed (step 11). The waiver evaluation will consider the points on Attachment 2.

Step 11 : Additional Technology Available

A review of alternate technologies will be performed relative to additional waste removal. If additional technologies are available, they will be deployed (step 12) and waste retrieval will resume. If additional technologies are not available, new technologies must be developed and deployed (staps 13 and 14). The tank farm will be held in interim status pending completion of the additional retrieval operations.

Step 12 : Deploy Technology and Perform Additional Retrieval

If additional retrieval technology is available, it is deployed and additional waste retrieval operations are performed. After retrieval operation, the waste residual is again determined (Step 7), followed by the tank goal compliance evaluation (Step 8).

Step 13 : Develop New Technology

If additional retrieval technology is not available, new technology is to be developed for the residue waste followed by deployment of the technology and additional waste retrieval operations (Step 12). After retrieval operation, the waste residual is again determined (Step 7), followed by the tank goal compliance evaluation (Step 8 ).

Step 14 : Closure Action

When the tank farm retrieval and waste residual assessment process is complete the closure operations will start. Completion of the retrieval operations will be documented in accordance with the closure plans. 


\section{WASTE RESIDUAL CALCULATION PROCEDURE, STEP 1}

Calculate Residual Waste Volume

1. Calculate Tank Volume

2. Measure/Calculate Waste Inventory via Topographical Mapping and Survey. Techniques.

3. Retrieve Waste

4. . Repeat Step 2.

Calculation Method:

For 75' Diameter Tanks (Full Diameter Tank (x))

xbar gal $=(100-A) \%$ (Total Volume of Waste/133 Tanks) $=$ Allowable Average Residual in full diameter tanks per Tank

where $A \% *=$ Goal or criteria for waste retrieval percentage.

For Small Diameter Tank (y)

ybar gal $=(100-\mathrm{A}) \%$ (Total Volume of Waste/16 Tanks $)=$ Allowable Average Residual in small diameter tanks per Tank

where $A \% *$ = Goal or criteria for waste retrieval percentage.

* Goal is $99 \%$ waste retrieval as defined in $M-45-00$ in equivalent volumetric measures. 


\section{EXCEPTION TO RETRIEVAL CRITERIA FOR SINGLE-SHELL TANKS}

The DOE shall retrieve tank waste in accordance with criteria detined in milestone $M-45-00$. This recovery criteria will be applied to each tank on a tank-by-tank basis. If the DOE does not believe that this criteria is achievable for a specific tank, DOE shall submit a request for an exception to EPA and Ecology. The request shall include, at minimum, the following information:

1. The reason DOE does not believe the retrieval criteria can be met.

2. The schedule, using existing technology, to complete retrieval to the criteria - if possible.

3. The potential for funre retrieval technology developments that could achieve the criteria, inciuding estimated schedules and costs for development and deployment.

4. The volume of waste proposed to be left in place, and it's chemical and radiological characteristics.

5. Expected impacts to human health and the environment if the residual waste is left in place.

6. Additional information as required by EPA and/or Ecology.

The above information shall be submitted within 120 days of the decision by DOE that continued retrieval actions will not result in further waste removal. : Upon receipt, EPA and Ecology shall provide a response within 60 days, in which they will either approve the exception to the criteria, in which case retrieval will be considered complete for the tanks in question, or they will deny the . request. If the request is denied the DOE must continue to attempt to retrieve the tank wastes until the criteria is met for the tank, or they may choose to enter into the RCRA dispute resolution procedures of the Agreement. If an exception to the criteria is approved, the closure plan for the SSTs must be modified to address the remaining residual waste. 


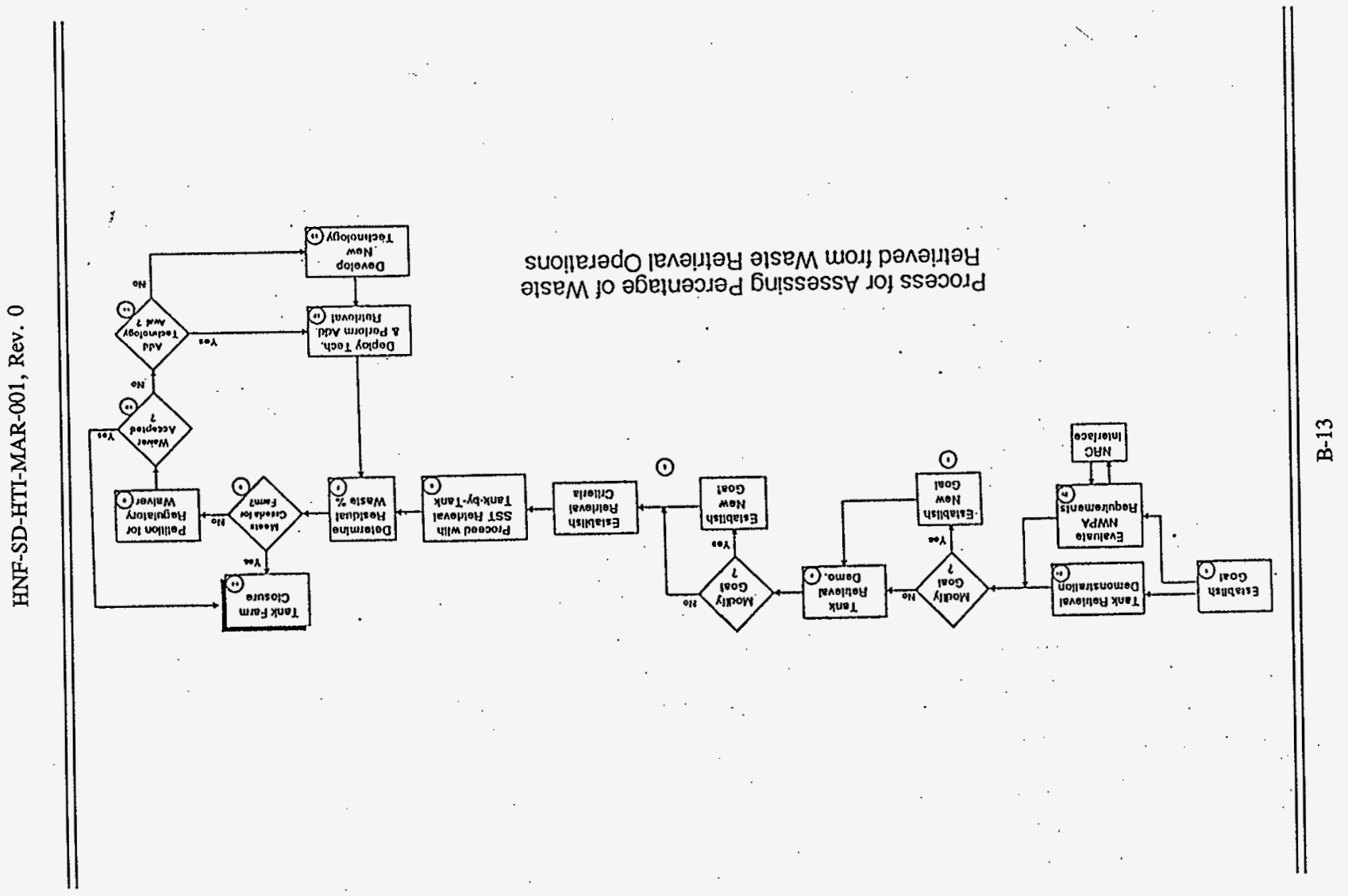


HNF-SD-HTI-MAR-001, Rev. 0

Figure B-1. Process for Assessing Percentage of Waste

Retrieved from Waste Retrieval Operations.

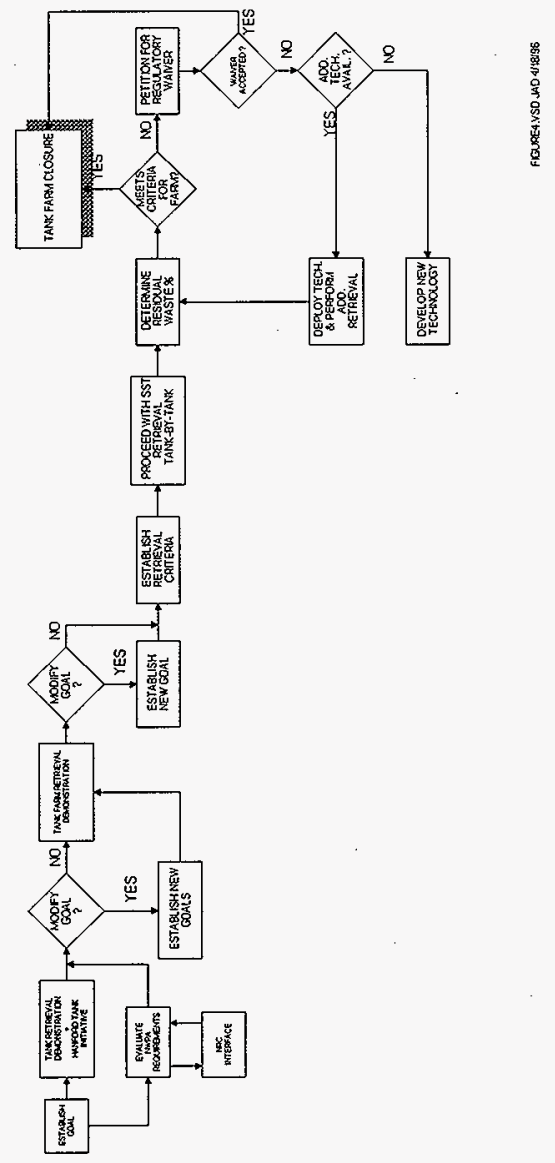


HNF-SD-HTI-MAR-001, Rev. 0

\section{APPENDIX C \\ External Constraints and Requirements \\ for Hanford Tanks Initiative}




\begin{tabular}{|c|c|}
\hline 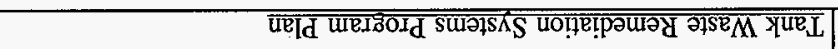 & 8S-26-Td/AOC \\
\hline 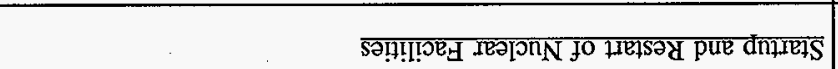 & $\begin{array}{r}\text { IE.08tS } \\
\text { دәpro GOC }\end{array}$ \\
\hline 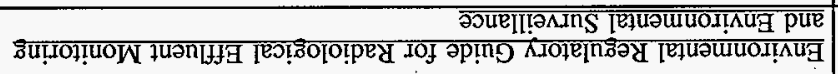 & LELLO-Hت/EOC \\
\hline 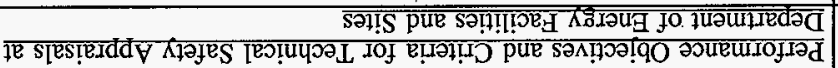 & ऽELO-Hヨ/घOC \\
\hline 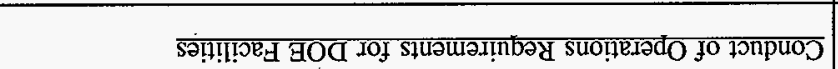 & $\begin{array}{r}6 I^{\circ} 08+\mathcal{S} \\
\text { دәрıо } \mathrm{BOC}\end{array}$ \\
\hline 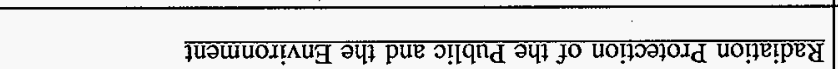 & $\begin{array}{r}\text { S’00tS } \\
\text { دәріО घOव }\end{array}$ \\
\hline 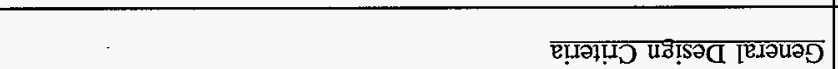 & $\begin{array}{r}\forall 0^{\circ} 0 \varepsilon t 9 \\
\text { xəpro gOव }\end{array}$ \\
\hline 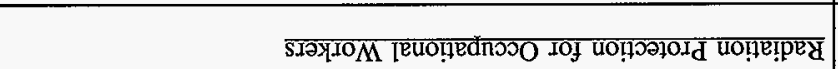 & $\begin{array}{l}\text { II } 08+S \\
\text { IәрIO Goव }\end{array}$ \\
\hline 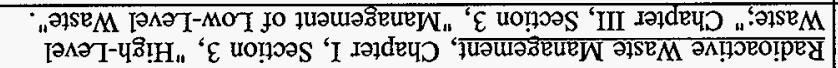 & $\begin{array}{r}\forall Z^{\circ} 0 z 8 S \\
\text { Iәр.о GOव }\end{array}$ \\
\hline 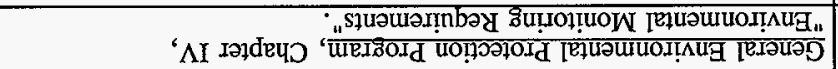 & 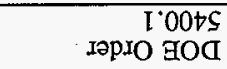 \\
\hline 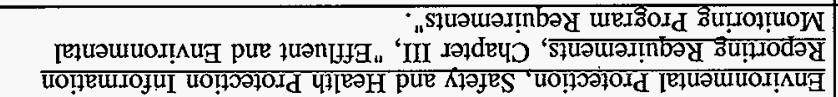 & 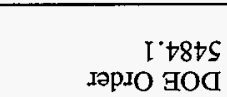 \\
\hline 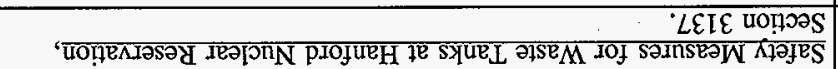 & $\begin{aligned} \text { OLS-I0I } \\
\text { MET ग!̣qnd }\end{aligned}$ \\
\hline 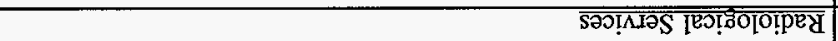 & SE8 ४ㅂㄱ OI \\
\hline 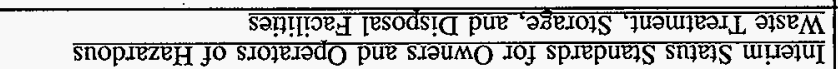 & 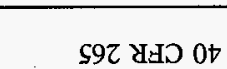 \\
\hline 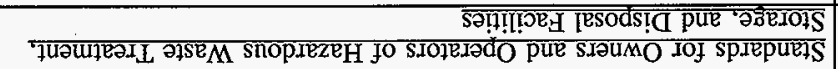 & t92 ชีว 0t \\
\hline 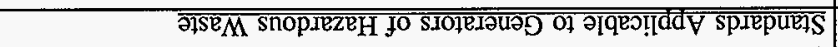 & 292 ชแว $0 t$ \\
\hline 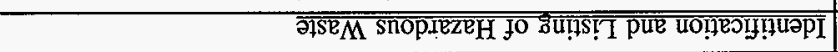 & โ9Z \&dग 0t \\
\hline 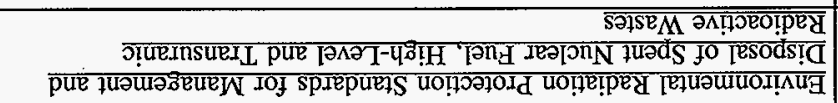 & I6I ช ชอ $0 t$ \\
\hline 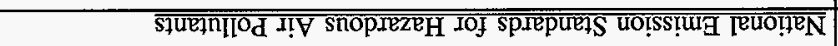 & 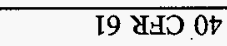 \\
\hline 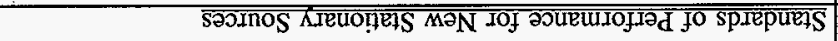 & 09 \&ดว 0t \\
\hline 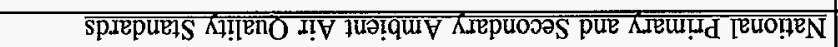 & $0 S$ \&HD $0 t$ \\
\hline 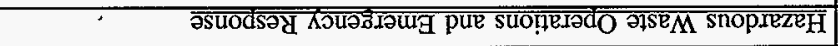 & 0ZT०0I6I ४HD 6Z \\
\hline & 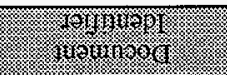 \\
\hline
\end{tabular}




\begin{tabular}{|c|c|}
\hline 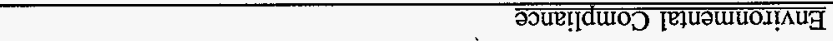 & S-L-WD-DHM \\
\hline 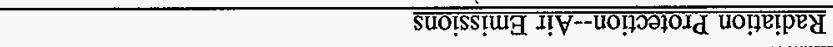 & $\angle \succ Z-9 \triangleright Z \supset \forall M$ \\
\hline 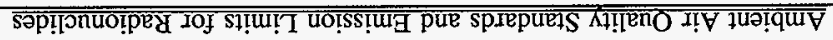 & $08 t-\varepsilon L I D \forall M$ \\
\hline 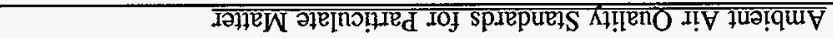 & $0 L t-\varepsilon L I S \forall M$ \\
\hline 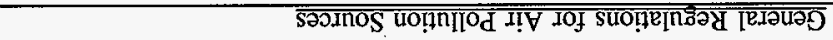 & $00 t-\varepsilon L I D \forall M$ \\
\hline 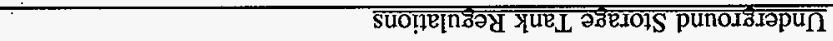 & $09 \varepsilon-\varepsilon L I \mathcal{S \forall M}$ \\
\hline 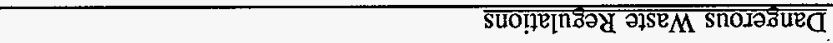 & $\varepsilon O \varepsilon-\varepsilon L I D \forall M$ \\
\hline 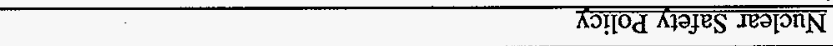 & I6-SE-NGS \\
\hline 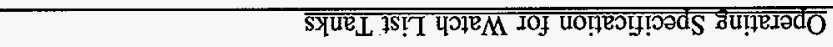 & $0 \varepsilon 000^{-I S I-L-G S O}$ \\
\hline 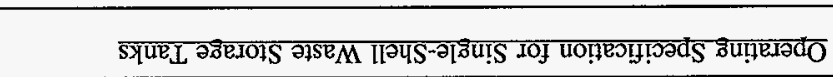 & $\begin{array}{r}E 10000 \\
\text {-ISI-L- } 2 S O\end{array}$ \\
\hline 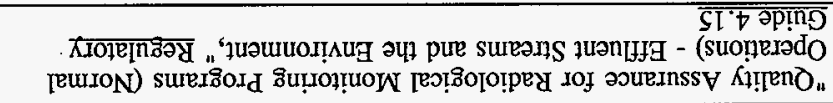 & SI ${ }^{\circ}$ วp!̣ı DYN \\
\hline & 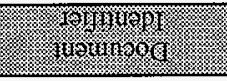 \\
\hline
\end{tabular}




\begin{tabular}{|c|c|c|c|c|c|}
\hline \multicolumn{6}{|c|}{ DISTRIBUTION SHEET } \\
\hline To & \multirow{2}{*}{\multicolumn{3}{|c|}{$\begin{array}{l}\text { From } \\
\text { HANFORD TANKS INITIATIVE } \\
\text { PROJECT }\end{array}$}} & \multicolumn{2}{|c|}{ Page 1 of 1} \\
\hline DISTRIBUTION. & & & & \multicolumn{2}{|c|}{ Date $9 / 18 / 97$} \\
\hline \multirow{2}{*}{\multicolumn{4}{|c|}{$\begin{array}{l}\text { Project Title/Work Order } \\
\text { HTI - HNF-SD-HTI-MAR-001 }\end{array}$}} & \multicolumn{2}{|c|}{ EDT No. 622801} \\
\hline & & & & \multicolumn{2}{|c|}{ ECN No. } \\
\hline Name & MSIN & $\begin{array}{l}\text { Text } \\
\text { With All } \\
\text { Attach. }\end{array}$ & Text Only & $\begin{array}{l}\text { Attach./ } \\
\text { Appendix } \\
\text { Only }\end{array}$ & $\begin{array}{l}\text { EDT/ECN } \\
\text { Only }\end{array}$ \\
\hline $\begin{array}{l}\text { CENTRAL FILES } \\
\text { HTI PROJECT FILES (2) }\end{array}$ & $\begin{array}{l}A 3-89 \\
H 6-08\end{array}$ & $\begin{array}{l}X \\
X\end{array}$ & & & \\
\hline $\begin{array}{ll}\text { J } & \text { BLOOM } \\
\text { E } & \text { FREDENBURG } \\
\text { J } & \text { HUSTON } \\
\text { L } & \text { MCDANIEL } \\
\text { A } & \text { NOONAN } \\
\text { B } & \text { ROOT }\end{array}$ & $\begin{array}{l}\mathrm{H} 6-12 \\
\mathrm{H} 6-12 \\
\mathrm{H} 5-61 \\
\mathrm{H} 6-12 \\
\mathrm{~K} 9-91 \\
\mathrm{H} 6-12\end{array}$ & $\begin{array}{l}X \\
X \\
X \\
X \\
X \\
X\end{array}$ & & & \\
\hline
\end{tabular}

